\title{
Sawankhalok Masterplan for Tourism Journey in World Heritage areas of Historical Districts Sukhothai - Si Satchanalai and Kamphaeng Phet
}

\author{
Surasak Kangkhao ${ }^{1 *}$ and Thale Kangkhao ${ }^{2}$ \\ ${ }^{I}$ Department of Architectural Education and Design, Faculty of Industrial Education and Technology, King \\ Mongkut's Institute of Technology Ladkrabang, Bangkok, Thailand \\ ${ }^{2}$ School of Architecture and Design, King Mongkut's Institute of Technology Thonburi, Bangkok, Thailand
}

\begin{abstract}
This research investigated the community engagement levels of local organizations and community leaders in Sawankhalok district with a proposed master plan to develop strategic models for creative tourism and sustainability through sustainable development goals from the United Nations. The objective of Sawankalok masterplan is to create a mobility mechanism for connect Sukhothai - Si satchanalai - Kamphaeng Phet Historical Parks, UNESCO World Heritage sites to become the main tourist destination in the future. The project focuses on the capacity of culture to improve the quality of life and seeks to recover the historical link among culture, co-creation development, and sustainability. Based on this context, this paper analyzes the main problems and the research results showed the following: 1) As for the implementation and operational framework on the Sawankhalok Master plan for Tourism journey in World Heritage areas of Historical districts, the researcher found that. The plans and projects were able to develop the management of the cultural and historical tourism 2) The results of the strategic drafting found that the vision of the Sukhothai and associate towns World Heritage was to sustainably and co-creation the values of the Sukhothai and associate towns World Heritage.
\end{abstract}

Keywords: Community development, Sustainability, Mobility mechanism, UNESCO, Historical districts, Wood architecture, Sawankhalok, Tourism

\section{Introduction}

Sawankhalok district in Sukhothai province are rich of history and full of potential, the district are located at Bangklang town and represent as one of the province in Thailand then the town are merged with Sukhothai province which located on the both side of Yom's river. Sawankhalok area is the habitation area of local community in the past, the area rich of history, culture, and traditional lifestyle especially architecture characteristic and identity of local Chinese community in the area. From above reason, the Preservation and development of Chinese community along Yom river and important historical area such as train station, police station, and government office etc. the design and renovate of the above areas in term of culture tradition are very important to develop city through the process of engagement of the existing and coming area to create the most efficient outcome.

From the above reason, Research Team had an opportunity to study and analysis on the area of Sawankhalok district area. The research team conduct a 1 weeks field research to understand a current context and Situation which could be used for future development of master plan in Sawankhalok district. The project involves with study on history of district area and various research methods to find a possible solution for development strategy in the further development. 
Master plan for Tourism journey in World Heritage areas of Historical districts Sukhothai - Si Satchanalai and Kamphaeng Phet

\section{Strategic plan for Creative Tourism Strategy Model for World Heritage Site, A pathway of Connecting ASEAN Tourism Network community}

Si Satchanalai Historical Park-together with Sukhothai and Kamphaeng Phet counterparts constituted the Historic Town of Sukhothai and Associated Historic Towns that were collectively registered as a tripartite UNESCO World Heritage site in 1991. (United Nations Educational, Scientific, and Cultural Organization (UNESCO), n.d.)

After research investigated the satisfactory levels of local organizations and community leaders by examining a number of community located in the vicinity of the historical park, the upcoming discussions initially evolved around the heritage of both tangible and intangible with a proposed master plan to develop strategic models for creative tourism in 3 Main areas of historical sites in Si-Satchanalai, Sukhothai, and Kamphaeng Petch.

The international cooperation from several institutions of higher education has establish an academic network on UNESCO World Heritage sites along the East-West Economic Corridor (EWEC) was signed at King Mongkut's Institute of Technology, Ladkrabang (KMITL) on June 1,2018. Since then the proposed to create a master plan to develop a strategic model for creative tourism at Si-Satchanalai Historical Park has become a pilot project that

\section{The Community heritage engagement}

The project is participated with local populace, important stakeholders, Local Experts, Specialist, and Scholars. To Purpose a creative tourism strategy model, the project applied coordination, cooperation, and collaboration (3C) as a strategy to deal with various group who participate in the program. (Rockwood, 1995a) (Rockwood, 1995b)

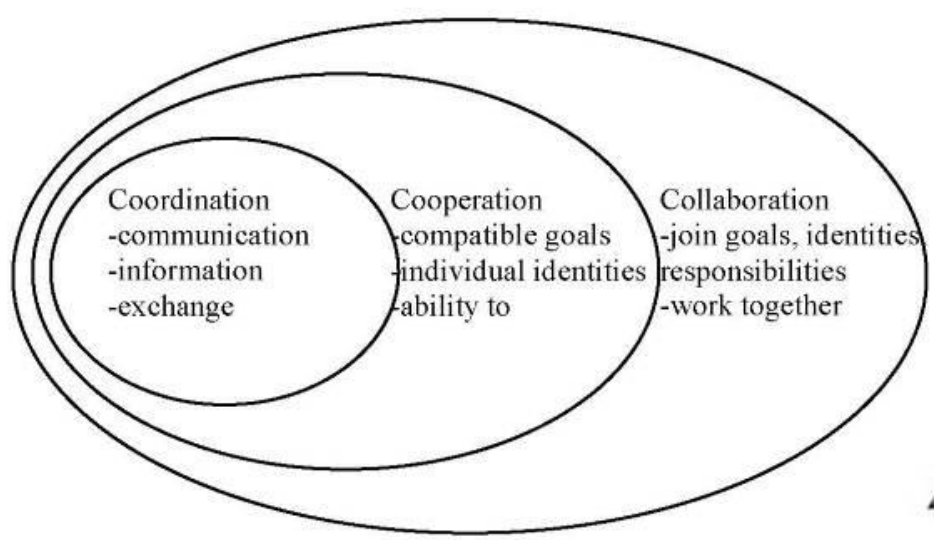

Figure 1 A diagram portraying the mechanism of the 3Cs approach (Louhapensang,

Chaturong; Kangkhao, Surasak, 2018) 


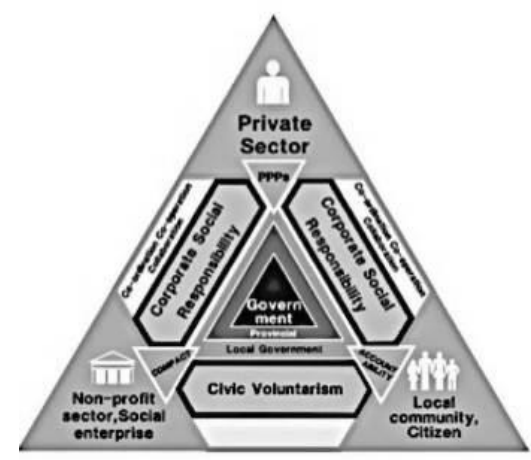

Figure 2 A diagram exhibiting the mechanism of the participatory theory serving as a modus operandi for the creative Tourism strategy Model (Louhapensang, Chaturong; Kangkhao, Surasak, 2018)

Moreover, the creative tourism strategy model incorporated two dimensions of the objectives. First, the project try to formulate a long term development framework for quality tourism, emphasizing on strategy making and planning, extending corporation, constitution, and coordination, product development and diversity, marketing and promotion, infrastructure, also incorporate with impact of tourism to local communities. Second, a shortterm action plan for urgent action to start the sustainable tourism development and preparation for the area.

(Kaewsayar \& Chamnongsri, 2012)

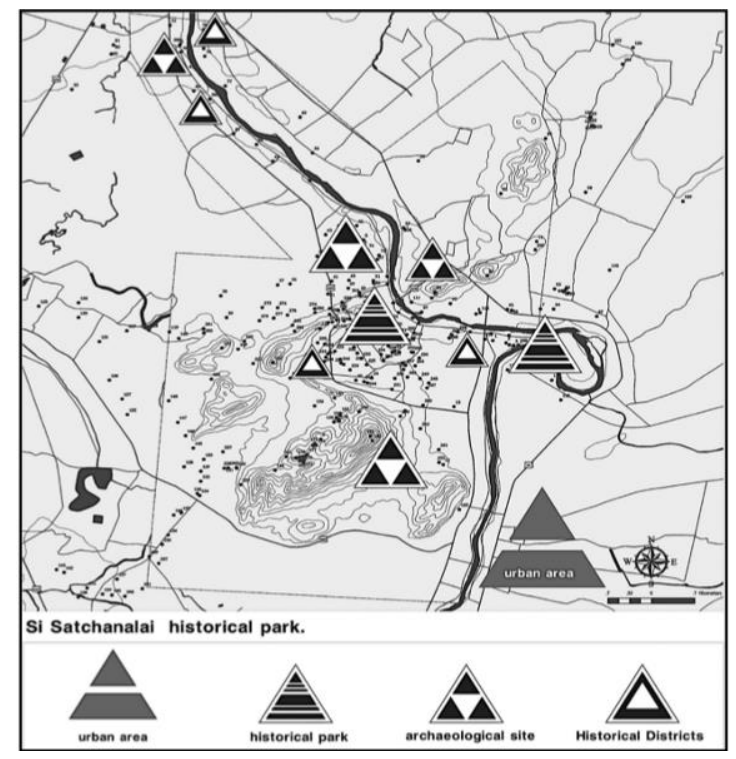

Figure 3 Location map of UNESCO World Heritage Site and Historic town of Si-Satchanalai (Louhapensang, Chaturong; Kangkhao, Surasak, 2018)

\section{Creative tourism strategy for Sawankhalok city}

Sukhothai city and Si-Satchanalai city are rich of historical area in both tangible and intangible culture. The project has continued through 3 main areas for the purpose of strategy development and coordination, cooperation, and collaboration (3C) 
Sawankhalok are located between both cities. The popularity for tourism businesses of Sawankhalok might not compare to Si-Satchanai and Sukhothai city. However, the Area of Sawankhalok are used to be one of the most important cities for historical stud, culture, logistic, and economic strategy in the past. The city is currently facing with the low rate of population and sustainable tourism in the district. The project starts through the field study, archive study, building survey followed with the conclusion for the present condition of the area then providing strategy for tourism strategy in Sawankhalok.

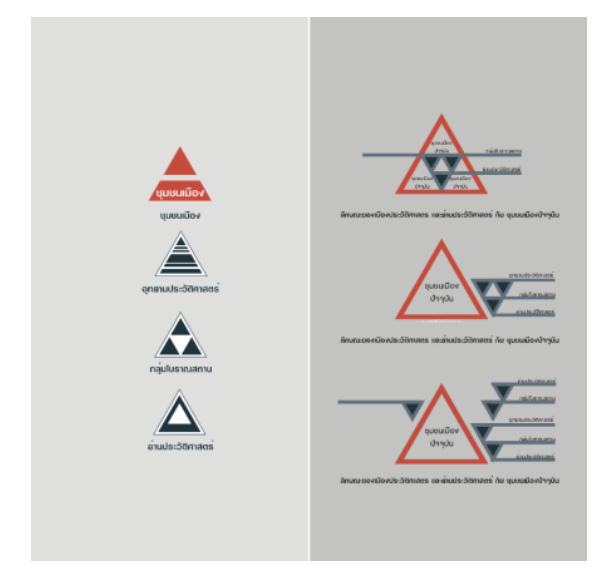

Figure 4 Analysis of Character of heritage city

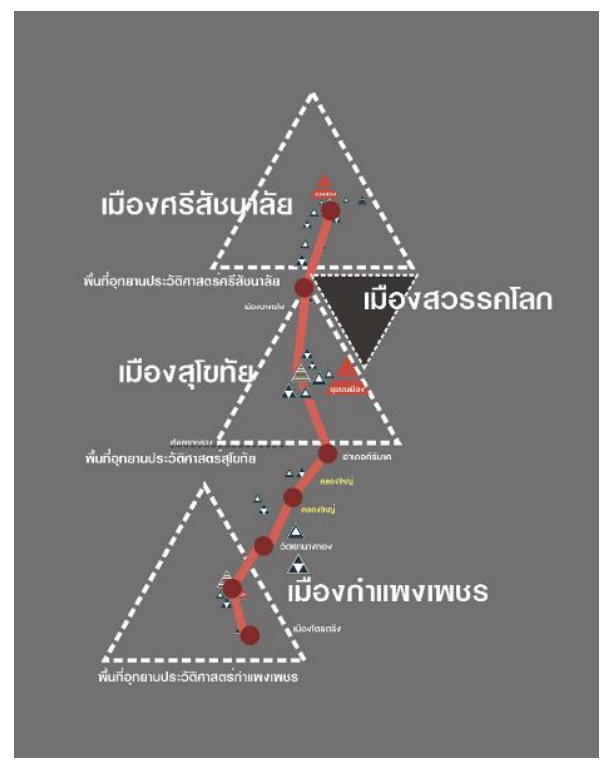

Figure 5 Creative tourism in Si-satchanalai, Sukhothai, and Kamphangpetch

\section{Studying physical characteristic and current situation in Sawankhalok District}

In the present, sawankhalok could not describe as one of the important district in Sukhothai for economy or development strategy, however, there are many history and evident that record Sawankhalok as one of the most important Area of Thai people in the northern part which the area carried a long history and culture by itself until present. 


\section{Current Status of Sawankhalok in $20^{\text {th }}$ century Research methods to Study Sawankhalok District}

\section{History of Sawankhalok}

The origin of Sukhothai culture come from a lowland area along the Yom River, Which Call Chaliang community. The community are developed and become Si-Satchanalai city which described in Wat Sichum's monolith as Sukhothai's capital city of Si-Satchanalai in 1250. During the time over Sukhothai as a capital city, the city was booming with the belief of Buddhism religious and Buddhism Culture that Following the stone inscription of King Ramkhamhaeng "in 1209 BE after worship of the budha relic in sixth month, the relic was buried in the middle of Si-Satchanalai to construct the Buddhist pagoda over its" (Fine Arts Department, n.d.)

After Ayutthaya had control over Sukhothai city in 1378, King Borom Rachathirat I tried to take control over Sukhothai and other surrounded cities under the centralize idea by eliminating the local governors and forcing all the local governors had to follow the order of Ayutthaya Kingdom. From above reason, Local power reject to be under control of Ayutthaya kingdom and decided to surrender under the power of Lanna Kingdom on the north. Si-Satchanalai has change its name and had become call Chiang Khuen city. There is no record on how long did Si-Satchanalai was under the control of Lanna Kingdom, but after the end of King Tilokkarat, SiSatchanalai had been under the Ayutthaya Kingdom Power, during King Borommatrailokkanat, it was also the first time that the name Sawankhalok appeared in the record of history.(Sawanvaranayok National Museum, 2020)

In the late of 18th century, the surrounding condition of colonization era from western country has force the country to reform the political power strategy. (Rajanubhab, 2002) while the early phase of government development process is not efficient enough because many areas still influence by local leader, until 1880 when the king has started to regain a full power to control over Siam. King Rama VI decided to transform the political strategy by terminating the traditional city management call "governing town" which the leader power continue through the family members of the previous leader. All the local nobilities are officially removed from the power, Ministry was responsible to nominate the local governor who had been trusted by the King to control every individual county in Siam (Bunnag, 2005). Thai separate into 3 main parts of governor transform the current control system into new political strategy which similar to the British government system in Burma and Malaysia (Wikipedia, n.d.) which start in 1897. There are Central government, county government, and District Government.

Sawankhalok has force to merge area with Phitsanulok County on the east side of the city (Kraipakorn, n.d.) (Wikipedia, n.d.). During Sawankhalok under Phitsanulok county, the rate of population in Phitsanulok is pretty low while people in Sawankhalok are mostly involve with Agriculture sector, and the living condition of people in the county was in a good condition (Thai Government Gazette, 1900)

\section{The rise of Teak businesses and railway transportation in Sawankhalok}

The Siam government signed the Chiang Mai treaty of 1874 required Siam government to provide a royal protection for British forest company and businesses in Lanna Kingdom, the treaty has affect the city along the river and transform culture and lifestyle of people along the river basin. This treaty has allowed Burmese, Mon, and Shan come to do teak business in Siam, but the most important is the international company got involve with this business in Siam, this because the trade could provide 100percent profit as a return to this western company in their homeland. This western has become a powerful over other companies in the teak business. (Wattananikorn, 2018) 
The location of teak business was operated wildly in the northern part of Thailand, such as Chiang rai, Lam phon, Lam phang, Phrae, Nan. Later, the teak business also expanded into the lower part of north region in Sawankhalok, Sukhothai, Kam Phangpetch, and Uthaithani.

(Songsiri, 2016)

After the teak business has been invent to Sawankhalok, the district became the first rafting station on Yom River. Raft station was the place where individual teak was gathered and transform into a raft. The teak business had created work for local people while during the time, while some families in Sawankhalok also involved with the business.

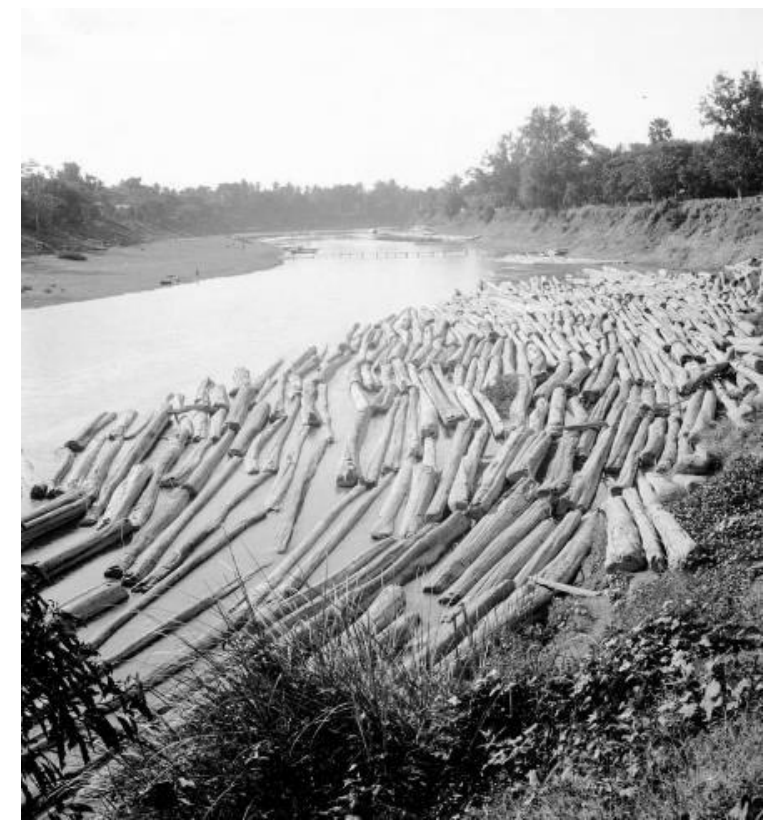

Figure 6 Sawankhalok Teaks 1936 (konsilaat, 2019)

Simultaneously with the invention of railway system into Thailand also increase the popularity of Sawankhalok. King Rama V has concern about the development of transportation which could help to generate income to the countryside of Thailand, meanwhile the rise of western colonization era from British and French has forced the king to concern more about a better strategy to control Siam during the time of crisis. (Chukaew, 2011)

The government decided to publish government gazette which presented the plan to develop a north railway route. In the early stage of development follow the government gazette, (Thai Government Gazette, 1910) it was clear that the first purpose of the development of this railway route to connect Sawankhalok with Tak province which located on the west side of Thailand and connect Nan river and Ping river together. Sawankhalok train station increase the number from a business and trading activity from two important markets in Uttaradit and Sawankhalok. The created of Sawankhalok train station in 1909 caused an impact to the surrounding of the area especially Sawankhalok which many activities have been generate for local people and the businesses such as Hotel, shop, and Restaurant has been built surround the area, the area also become the important transportation area for local people to commute into other area in Thailand.

\section{The end of foreigner teak companies and declining of Sawankhalok district}

In the early phase of teak business era, around 80 percent of the business are controlled over by foreigner company especially British empire however, In the reign of King Rama VI and VII, the government started a policy to promote more Thai people to involve with concession in teak business to provide a better benefit to the 
government. From above reason, the government promoted Thai company to be more involved with forest concession and limited the authority of foreigner companies.

However, the change of political power in 1932 from the absolute monarchy into democratic by people parties. Field Marshal Plaek Phibunsongkhram had promote Thai culture to be similar like other western country, this idea had been applied to the country's economy by promote Thai people to become a buyer and a seller for a teak business. (Songsiri, 2016)

In the same time, the coming of greater East Asia war had caused many impacts to teak businesses. In 1941, Thai government decided to withdraw the teak forest concession and every property from the 4 main foreigner companies in Thailand which follow the "Thai gazette about the control and manage property of foreigner in the time of emergency". Then they established Thai Forest Company which belong to the government to take over the forest concession.

In 1939, the prime minister, Field marshal Plaek Phibunsongkhram concerned about the important of Sukhothai province as one of the most important heritage site of Thailand history that need to be preserve for a younger generation. (Fine Arts Department, n.d.) From above reason, Prime minister announced to merge Sawankhalok province with Sukhothai. This event has caused a large impact to Sawankhalok district, the district become less important for economy strategy and development which become the reason of declining of Sawankhalok reputation until the present.

\section{Sawankhalok has become the nostalgia of the northern city in the 19th century}

After Sawankhalok become one of the districts in Sukhothai province, this had changed the position of Sawankhalok and future development in the district. After the construction of highway transportation for car has been introduce to the north region from the highway Road number 125 and 11 which has caused the decreasing the rate of railway transportation to the region. Consequently, reducing of tourism people in the area and effect to the businesses and service in Sawankhalok Area. Eventhough, many history and culture might disappear from Sawankhalok district, but after studying through Sawankhalok district, Book archive, and field research. There are still visible evident of the sawankhalok remain around the city such as building that could reflect the story of Sawankhalok.

\section{Demographic change of Sawankhalok District}

The research has study to the demographic change of current population in Sawankhalok district (Official Statistics Registration Systems, 1993). It could be seen that the number of populations in Sawankhalok district drop significantly from around 70000 people in 2009 to 50000 people in 2014 and remain the same to the present. Moreover, when the number of populations in Sawankhalok people divided into 4 different group of people, it could be seen that people between 41-60 years old are the highest group of people in the area and followed by people around 21-41 years old. From above data, this could be predicted that in the next $10-20$ years the area will have to deal with more elder people in society and require strategy to provide solution to deal with aging society in the future. 


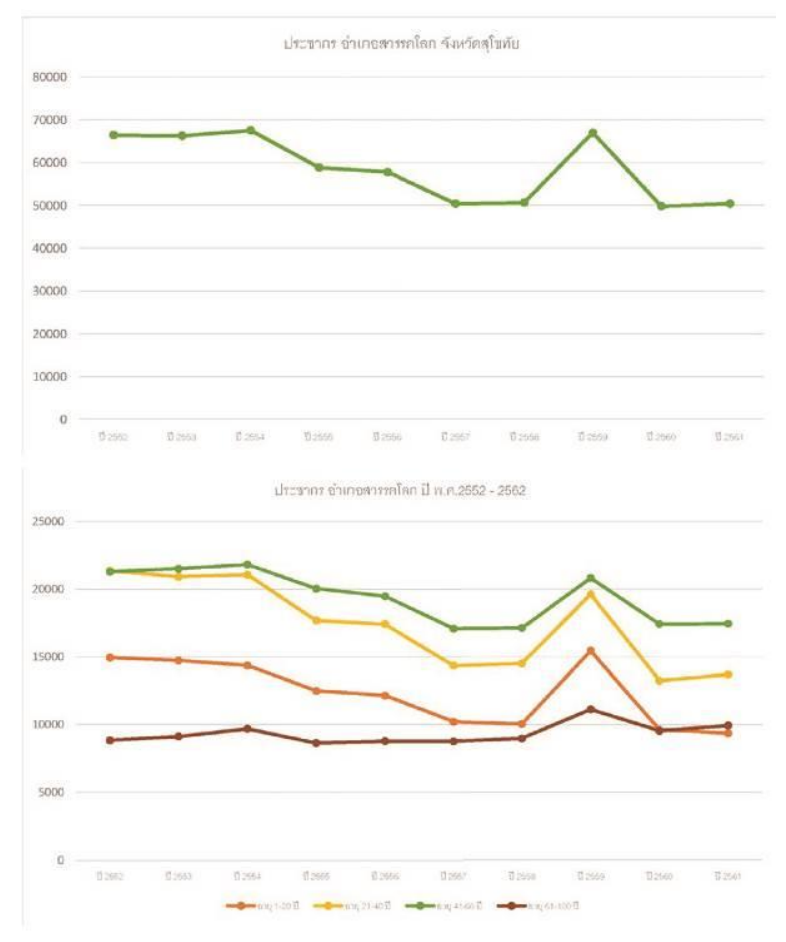

Figure 7 Sawankhalok Population Demographic

\section{Analysis of Local people character and activity in Sawankhalok district}

User in Sawankhalok district could be divided into 2 different group of people. There are government officers and local people in the area. People in the area have a similar habit and activity in their daily life. The project also focuses on activity which government officer and local people will participate in the area of the district which could be focus in the area of police department and governor department of the area.

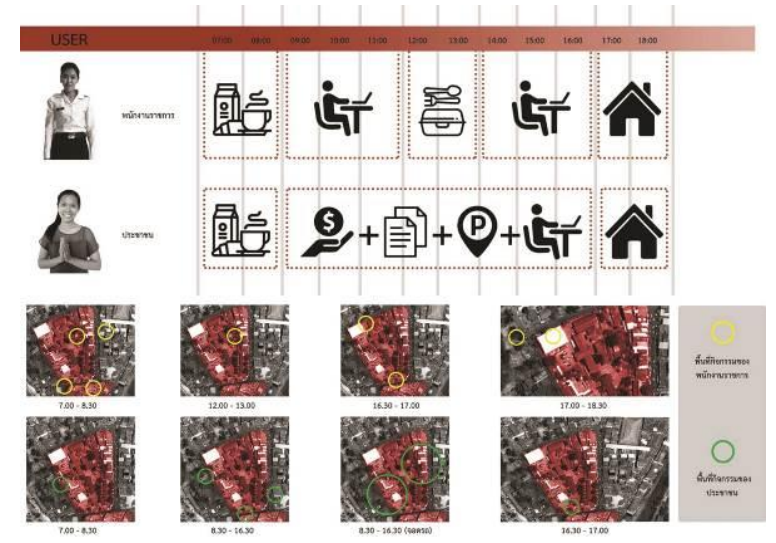

Figure 8 User Analysis Diagram

\section{Transport circulation and parking lot in research area}

Transportation and parking area are one of the main issues in the area. The area is rich of activity, shop, and business which attract many people to come to the middle of the city. The lack of good transportation force people to use personal car to access the area of Sawankhalok district. The yellow arrow represent the direction of the main circulation which the road are used for car, the diagram could be seen that the main circulation are surround the area of Sawankhalok old district area while the small road allow personal cars to access inside of 
the old district area in the middle part of area. While, it is obvious that the parking space or parking lot could be divided into 3 different type, permanent parking which surrounded the study area and cover both sides of the road which next to the train station and the government also provide parking space surround the area of district. Free parking could be seen in the small road or soi between buildings and local communities.
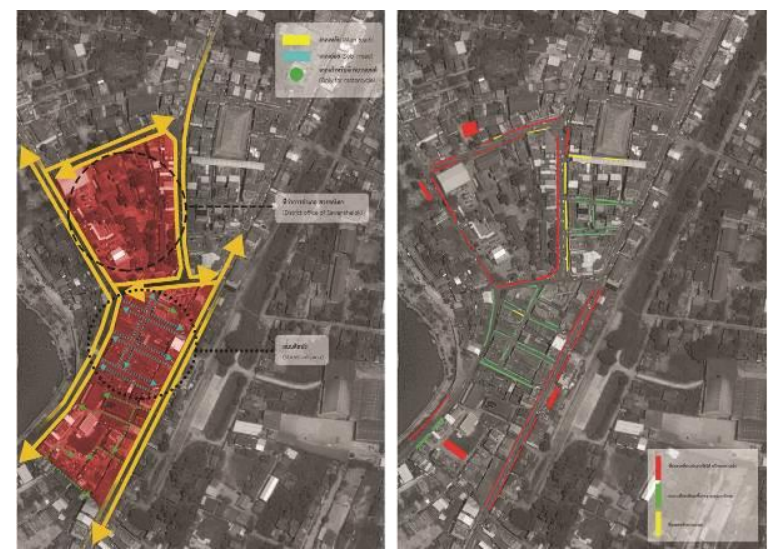

Figure 9 Transportation and Parking Lot Diagram

\section{Important historical area in Sawankhalok district}

Sawankhalok involves with many historical points which are located surround many areas in the city. According to this information has been advised from Ex-government figure which specialized in cultural and historical description and narrative for local area. (Duenpen, 2019) There are 15 places which is important to the area.

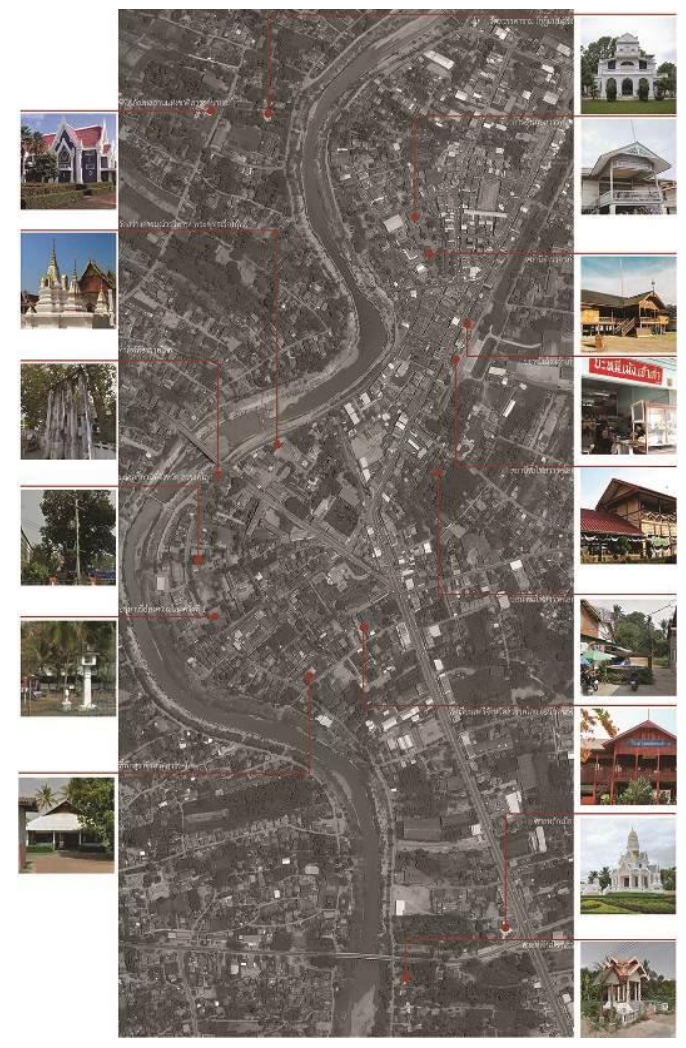

Figure 10 Historical Area Map 


\section{Methodology of research}

\section{In depth research from Sawankhalok people and community}

Information from physical characteristic of Sawankhalok is not enough to understand more complex relationship of people in community and invisible conflict or problem inside the community. From above reason, Research team are required to use different kind of methods to understand this issue.

\section{Research methodology}

This research used combined method of both qualitative and quantitative research method for study Sawankhalok district area. There are 2 types of Research methodology which has applied during Research trip at Sawankhalok district.

Interview technique- Qualitative research type on Interview video which collected in-depth information from people in the area especially leader in community, scholar in Sawankhalok district, New generation people around 30 people interview.

Observation technique - This research type is used to collect data about surrounding of the area especially traffic circulation and parking area which is very important. Also, using for Building survey to collect data about surrounding building in the area to evaluate the physical character of existing building and surrounding environment.

CapAsia technique - Student from Capasia experience Asia culture from collaborative projects, home stays, and field trips, the participants learn by transforming the experience into knowledge and reflecting about themselves, i.e., their environments, cultures, and the selves. As they learn about Asian cultures, make local friends, and help communities to achieve higher quality of life on their own terms, the experience will help them situate themselves in today's changing world. (Ball State University, 2020)

\section{Discussion with Local governors in Swankhalok district and Sukhothai}

Research project has concern about the impact of the project that would be able to influence Sawankhalok and establish a solid outcome in the future. The project has continue to participate with local government to give a cler understanding and promote possibility. From the previous meeting, the research team have meet with the Sawankhalok Deputy chief to discuss about the field study and research on sawankhalok area, while during meet with the major of Sukhothai province, research team had discussed with the major to find a proper solution as a strategy to create a sustainable tourism for Sukhothai, Si- satchanalai, and Kamphang petch. Sawankhalok as a connecting routh between Si-satchanalai and Sukhothai city has been present to the major and show the possibility and benefit of this tourism strategy to the province. 


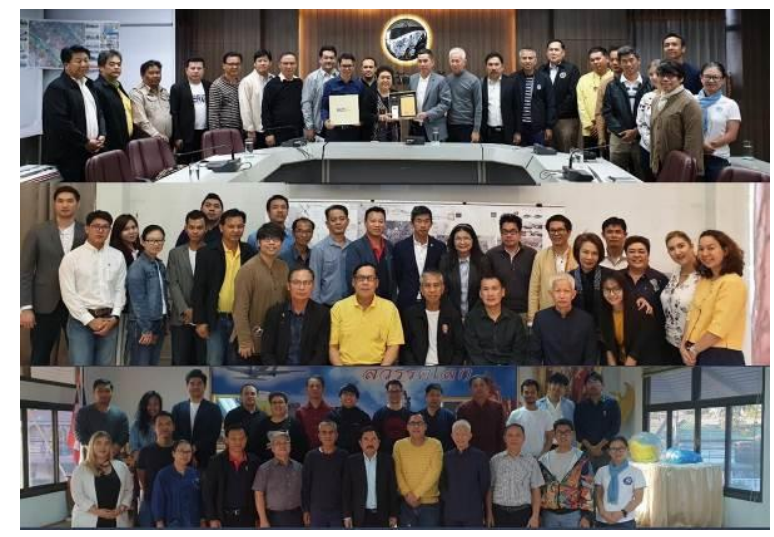

Figure 11 Meeting between business and goverment sector in Sukhothai and Sawankhalok

\section{In-depth interview research}

The survey team also focus on the local people to understand the current situation and problem from the root of the issue because of this team decided to use interview method and ask several question about change and transform of the existing context to the area. There are different feedbacks from the question and opinion on the idea of future development and improve for creative craft district. However, many local people tend to answer in the same direction that they believe atmosphere and local people is the most important element to improve the city, moreover they also give important into architecture preservation to save their atmosphere for the tourism businesses.

Group of interviews are focus especially on local people and community philosopher while local businesses owner also gives several different perspective and opinion to the places. Local artists also got involved in this project. The interview could be summarzie that Sawankhalok district can be described as slow life community but rich of architecture, history, and culture in the area. However, the area still lack of support and advertise to the tourist while there are many attraction places are located only center of the district area and disconnect to the other attraction places in the area and unable to create participation between local people and goverment which cause the problem to the process of development in the city

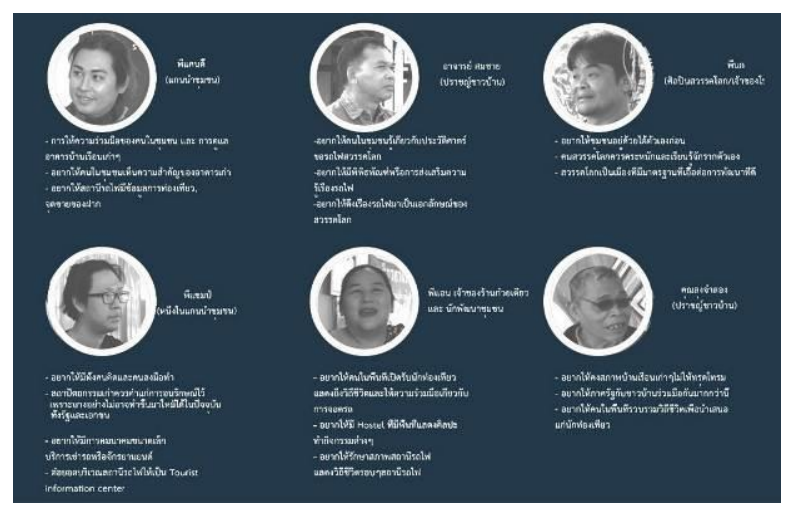

Figure 12 Interview Sawankhalok People 


\section{Building Survey research}

There are many interesting characters of architecture in Sawankhalok district which are valuable for conservation especially in the research area. From above reason, building survey are require keeping the information of current architecture type and condition on the existing site area for the beneficial use in the future. The survey is classified building into 16 different type of buildings such as house to large building in the area. Also, the buildings are evaluated through their present condition from historical building condition to building which is not relate to surrounding building and the existing context.

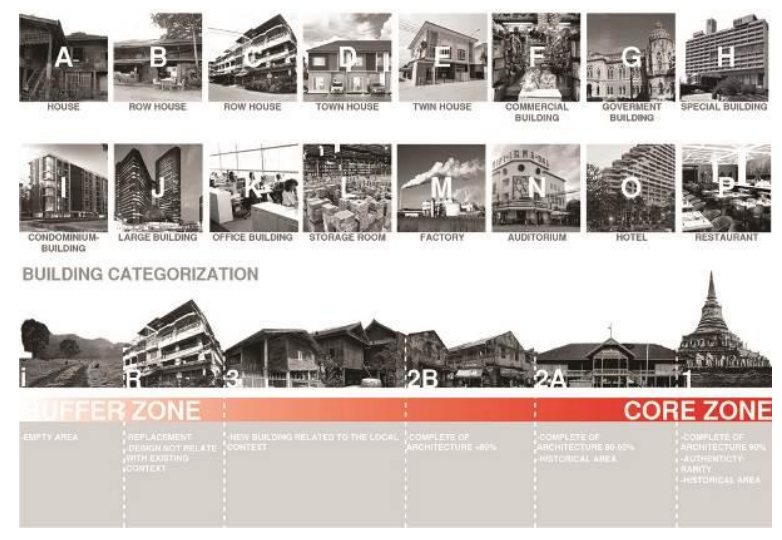

Figure 13 Building Categorization

The area could be divided into 4 different main areas Zone A, Zone B, Zone C, and Zone D. All the buildings are categorized with photograph and collage technique to illustrate all areas of the research while statistic of each zone present the current condition, material, and type of existing area

\section{Zone A}
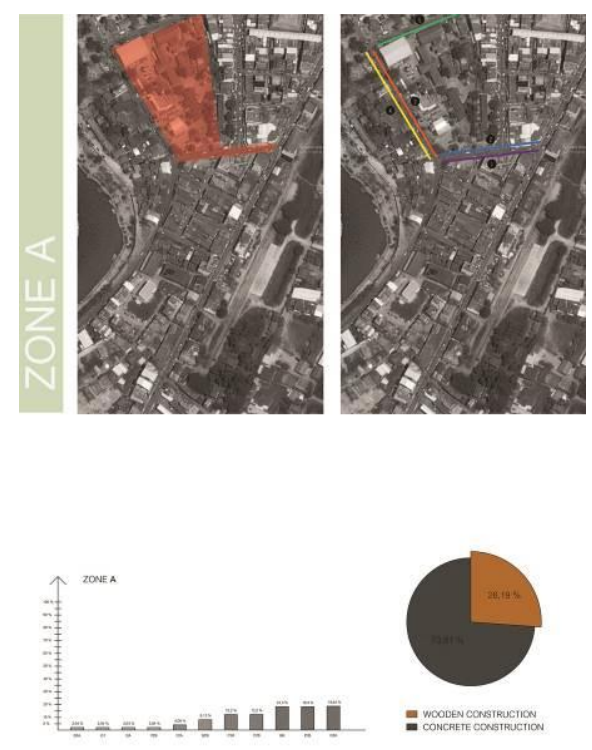

Figure 14 Zone A Area and Statistic 


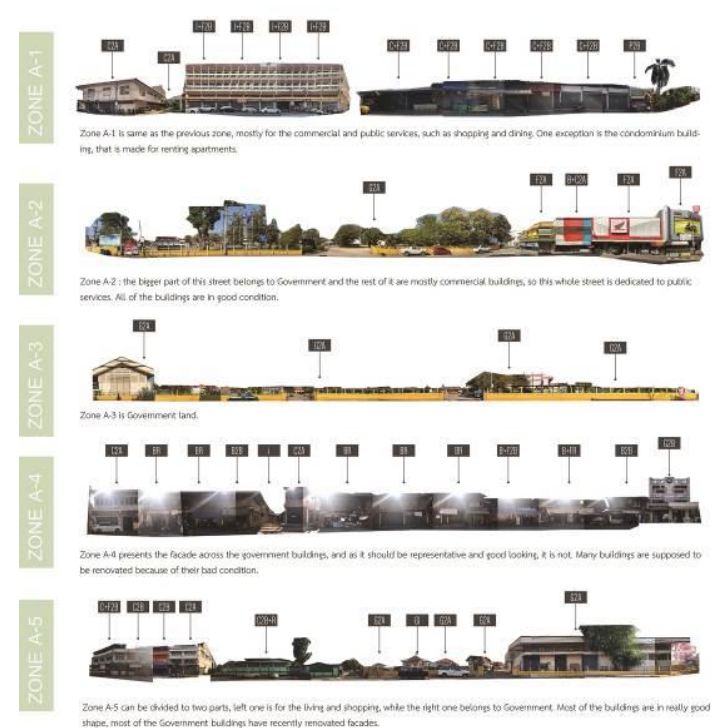

Figure 15 Zone A Facade Analysis

Zone A1: the bigger part of this street belongs to Government and the rest of it are mostly commercial buildings, so this whole street is dedicated to public services. All of the buildings are in good condition.

Zone A2: is same as the previous zone, mostly for the commercial and public services, such as shopping and dining. One exception is the condominium building that is made for renting apartments.

Zone A3 presents the facade across the government buildings, and as it should be representative and good looking, it is not. Many buildings are supposed to be renovated because of their bad condition.

Zone A4 is Government land.

Zone A5 can be divided to two parts, left one is for the living and shopping, while the right one belongs to Government. Most of the buildings are in really good shape, most of the Government buildings have recently renovated facades. 


\section{Zone B}
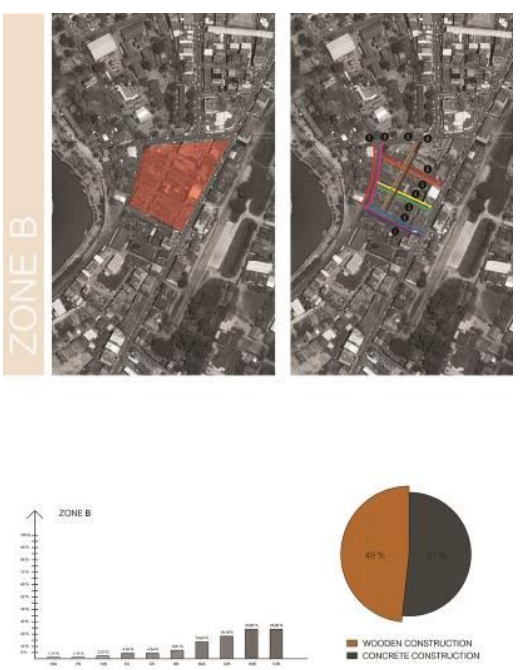

Figure 16 Zone B Area and Statistic

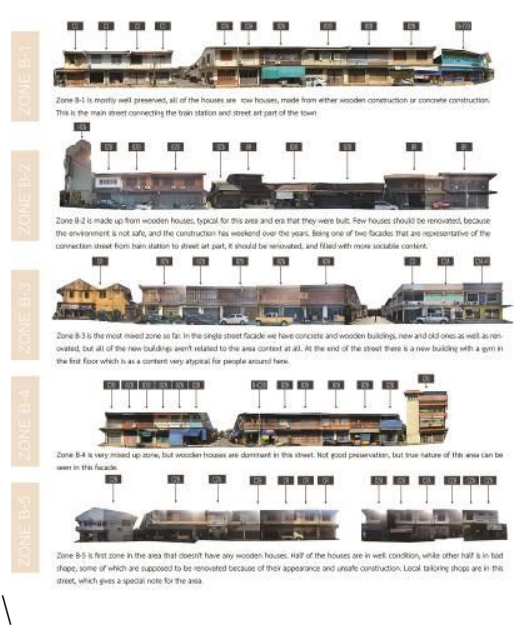

Figure 17 Zone B Facade Analysis 1 


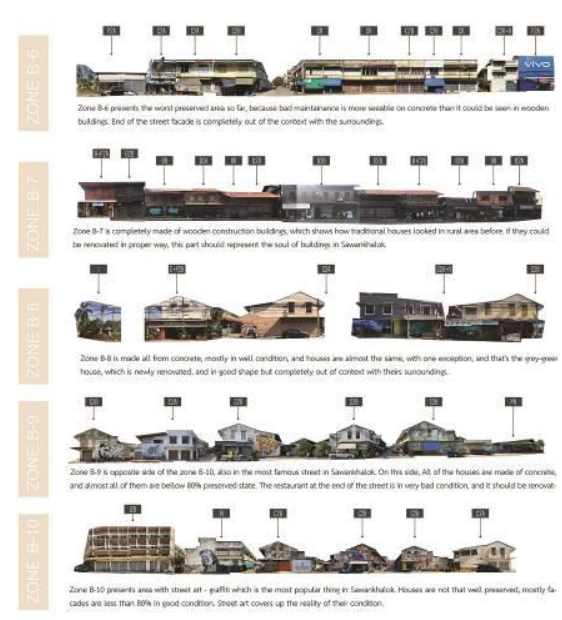

Figure 18 Zone B Facade Analysis 2

Zone B1 is mostly well preserved; all of the houses are row houses, made from either wooden construction or concrete construction. This is the main street connecting the train station and street art part of the town.

Zone B2 is made up from wooden houses, typical for this area and era that they were built. Few houses should be renovated, because the environment is not safe, and the construction has weekend over the years. Being one of two facades that are representative of the connection street from train station to street art part, it should be renovated, and filled with more sociable content.

Zone B3 presents area with street art - graffiti which is the most popular thing in Sawankhalok. Houses are not that well preserved, mostly facades are less than $80 \%$ in good condition. Street art covers up the reality of their condition.

Zone B4 is opposite side of the zone B3, also in the most famous street in Sawankhalok. On this side, all of the houses are made of concrete, and almost all of them are below $80 \%$ preserved state. The restaurant at the end of the street is in very bad condition, and it should be renovated.

Zone B5 is the most mixed zone so far. In the single street facade, we have concrete and wooden buildings, new and old ones as well as renovated, but all of the new buildings aren't related to the area context at all. At the end of the street there is a new building with a gym in the first floor which is as content very atypical for people around here.

Zone B6 is very mixed up zone, but wooden houses are dominant in this street. Not good preservation, but true nature of this area can be seen in this facade.

Zone B7 is first zone in the area that doesn't have any wooden houses. Half of the houses are in well condition, while other half is in bad shape, some of which are supposed to be renovated because of their appearance and unsafe construction. Local tailoring shops are in this street, which gives a special note for the area.

Zone B8 presents the worst preserved area so far, because bad maintenance is more seeable on concrete than it could be seen in wooden buildings. End of the street facade is completely out of the context with the surroundings. 


\section{Zone C}

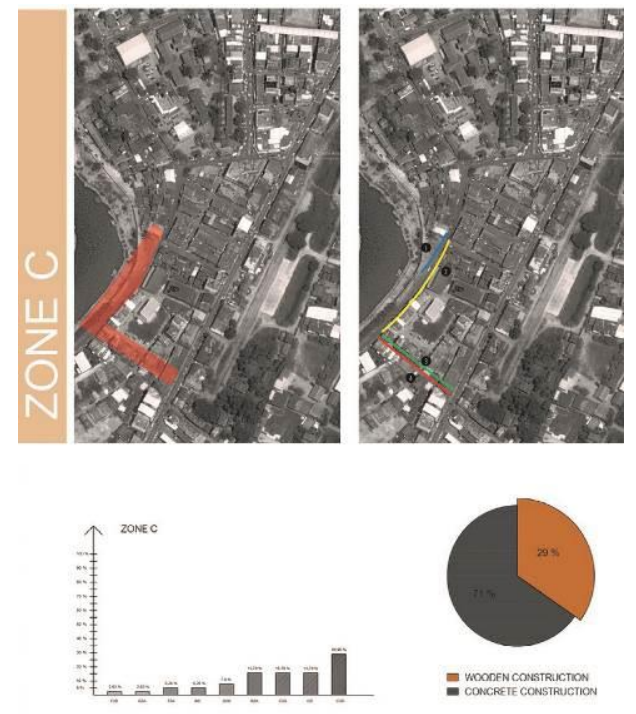

Figure 19 Zone C Area and Statistic

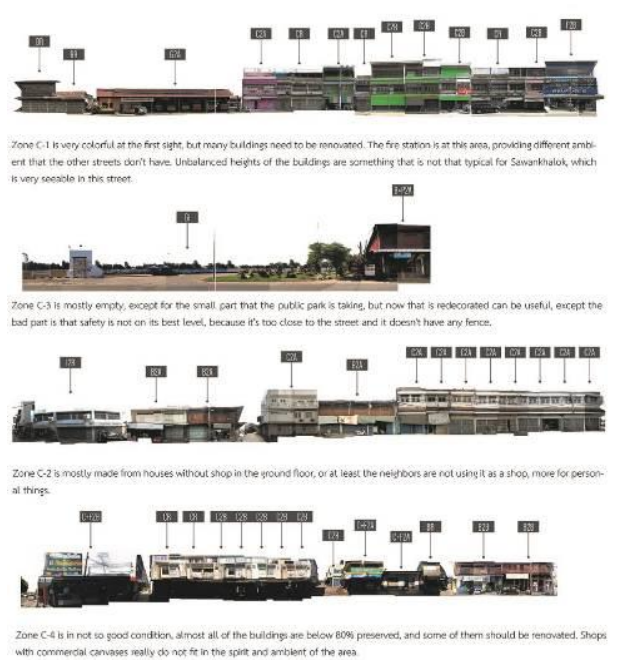

Figure 20 Zone C Facade Analysis

Zone $\mathrm{C} 1$ is very colorful at the first sight, but many buildings need to be renovated. The fire station is at this area, providing different ambient that the other streets don't have. Unbalanced heights of the buildings are something that is not that typical for Sawankhalok, which is very seeable in this street.

Zone C2 is mostly made from houses without shop in the ground floor, or at least the neighbors are not using it as a shop, more for personal things.

Zone C3 is mostly empty, except for the small part that the public park is taking, but now that is redecorated can be useful, except the bad part is that safety is not on its best level, because it's too close to the street and it doesn't have any fence. 
Zone C4 is in not so good condition, almost all of the buildings are below $80 \%$ preserved, and some of them should be renovated. Shops with commercial canvases really do not fit in the spirit and ambient of the area.

\section{Zone D}
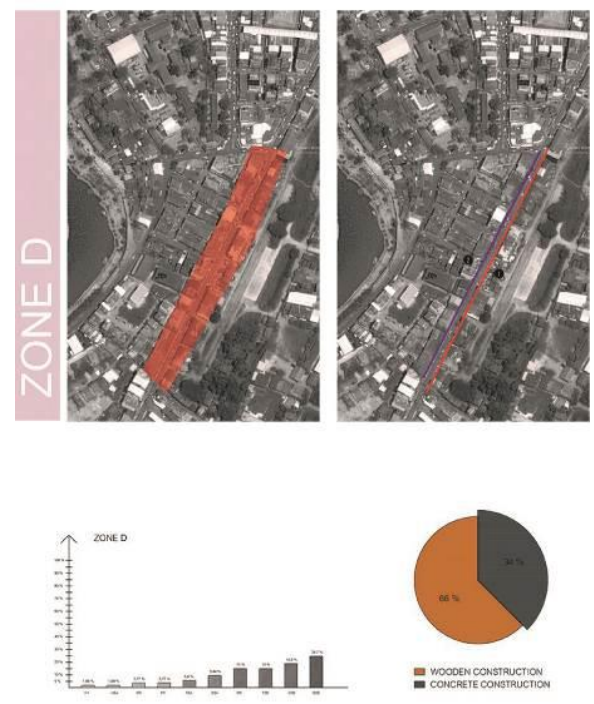

Figure 21 Zone D Area and Statistic

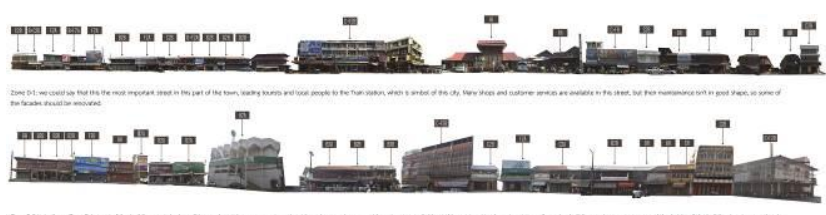

Figure 22 Zone D Facade Analysis

Zone D1: we could say that this is the most important street in this part of the town, leading tourists and local people to the Train station, which is symbol of this city. Many shops and customer services are available in this street, but their maintenance isn't in good shape, so some of the facades should be renovated.

Zone D2 is similar as Zone D1, most of the building are in bad condition, and could use some restoration. Many shops and commercial services are available at this part too. Inadequate mixture of wooden buildings and concrete ones, and the height of the building is not proportional, so urban landscape seems like it has lost its nature state.

\section{Result from the field research and study the current situation Sawankhalok}

The research has shown that Sawankhalok are facing with several issues which cause the problem to the city. The decreasing number of population, while local people are mostly elder people who lived in the area and running their family businesses for many generation. Tourism Authority of Thailand had started the project to tackle with the death of businesses and try to generate an income to local businesses in the area through street art which become as a tool to attract visitor into the area. However, after an interview with several scholars, Businessmen, Restaurant owners, and local governors. 


\section{Wood Architecture in Sawankhalok}

The study of Sawankhalok and building survey has revealed the interesting Architecture building in the area that could describe the event and history of Sawankhalok through the story telling from member of the family inside the building and the construction of the wood structure. After the survey, Sawankhalok already have several important buildings that represent the history of the city but the list of buildings concern only the government sector that represent only the history and story of the overall city and government but this building are lack of describe the daily life of local people and activity of people in the area. The building could conclude into 8 building which could be divided into 2 groups, government building and private building.

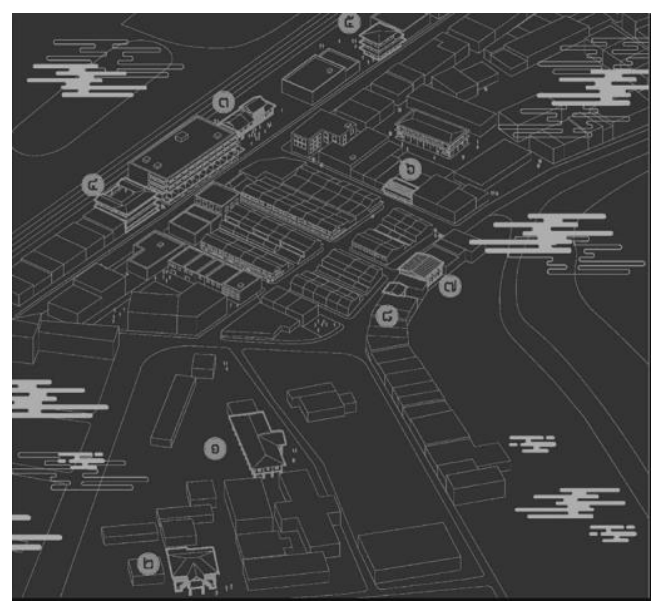

Figure 23 List of Wood Architecture in Sawankhalok

\section{Government building}

\section{Police station building}

Sawankhalok Provincial Police Station building (the old building) is a one-story wooden building with raised floor, hipped roof with cement-kite shaped tiles. There is a gable in the front of the porch and the stairway extends out from the front of the porch on both sides. The columns on the lower floor are made of concrete while the top columns are made of red wood. The walls, doors, and windows are made of golden teak, and the ceiling is using hardwood. The area on the upper floor is an open hall which use to display historical information of the police station and Sawankhalok, as well as tools used in the past such as, office equipment, police uniform, antique furniture, safe that used to save Sawankhalok government agencies' money, photos of significant events and important people etc. the importance of the history and architecture of the people in Sawankhalok and Sukhothai, resulting in the involvement of many sectors in the building reconstruction until the operation is successful. This is also a social value that can result in the conservation of Sawankhalok and other architecture such as Sawankhalok district office building, Sawankhalok train station Building and antique store house. (The Association of Siamese Architects under Royal Patronage, 2016) 


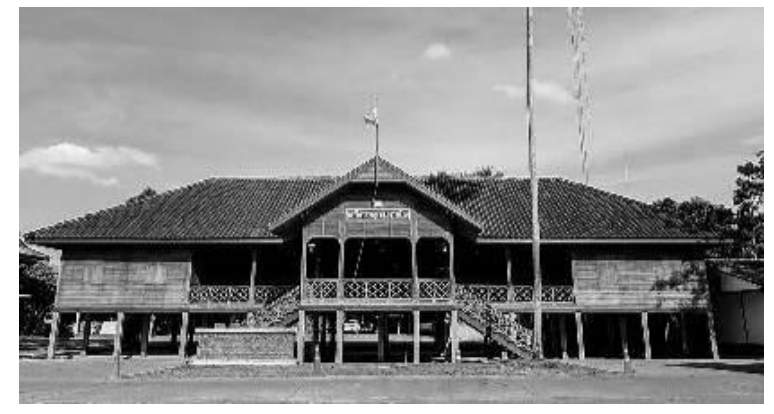

Figure 24 Sawankhalok Old Police Station (DASTA, 2019)

\section{Sawankhalok district office}

The Sawankalok district office building is very important as it relates to the royal proceedings of the King Rama IX. The district office has made a merit ceremony to commemorate His Majesty's grace on the occasion of the 59th anniversary of His Majesty the King Bhumibol Adulyadej and Her Majesty the Queen Sirikit traveled to Sawankhalok district on March 1, 2501 B.E. by using the Sawankhalok District Office Building as the residence. (Non-Formal education Sawankhalok district Sukhothai Province, 2010)

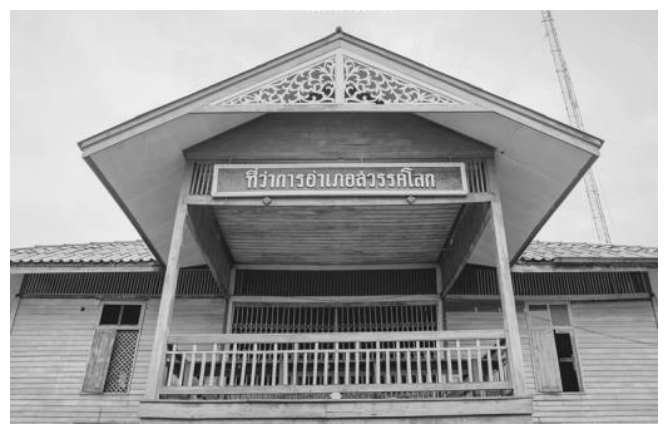

Figure 25 Sawankhalok district office (AntWorawit, 2016)

\section{Sawankhalok Train station}

The railway station was built separated from Ban Dara junction in Uttaradit province and then came into Sukhothai. In the past, if people from Sukhothai Kamphaeng Phet and Tak will travel to Bangkok, they have to wait to catch a train at Sawankhalok Station, which is the northwest railway terminal station. Moreover, it is also a route for transporting goods such as logs and forest products from North West side down to Bangkok as well. Currently, Sawankhalok Railway Station is still open for service. (Cha-umpol, 2018) 


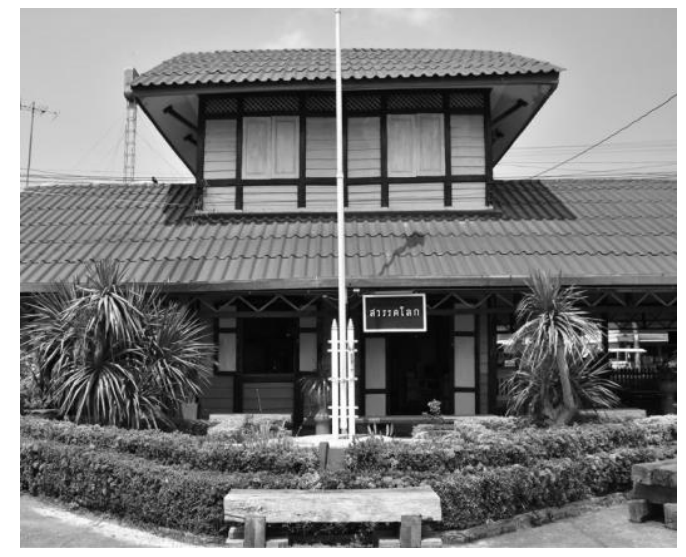

Figure 26 Sawankhalok Train Station (DASTA, 2019)

\section{Residential and Private building}

\section{Sermthai building}

Sermthai building could be describe as the first generation of row house building in Sawankhalok. The house owner Kimpong Sowittiyakul (Sowittiyakul, 2020)the area used to transfer products from river basin to the train cargoes, Later on, the area has become a community area, while the building has become a convenient store for the surrounding area. The building still use the old kite ceramic rooftile to construct the roof

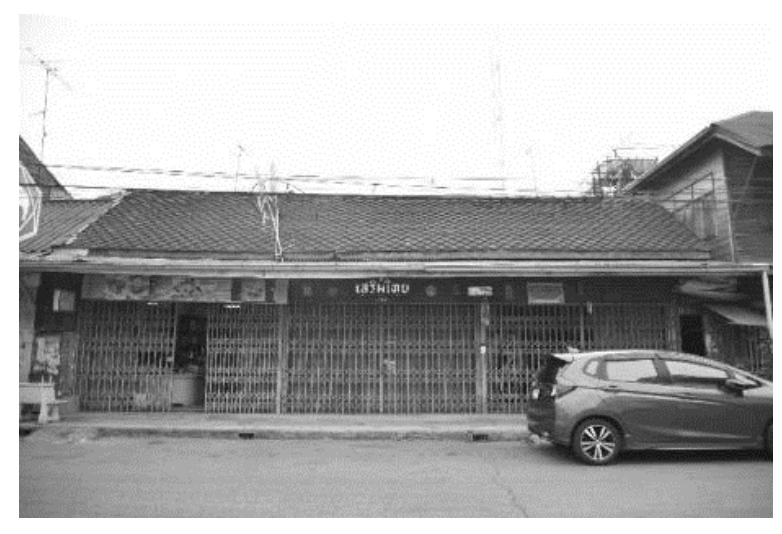

Figure 27 Sermthai Building

\section{Khun prani building}

Originally the Chindapracha family were Chinese who come to live in Bangkok and moved to Sawankhalok during the reign of King Rama VI. Khun Pranee Chinpracha, a Chinese citizen who gained reputation for helping housing authority and government staff in Sawankhalok. He was granted a royal title of Khun Pranee and received some land. He also one of the pioneers to build a first Chinese school for the Chinese student in Sawankhalok with other family in the area. Moreover, Khun pranee Chinpracha also involve with the teak businesses with the foreigner companies like dutch company (East Asiatique) and British company (British Borneo Company limited). In the present, the house belong to his grandson which currently runs a kerosene businesses in the Sawankhalok district. (Jindapracha, 2020) 


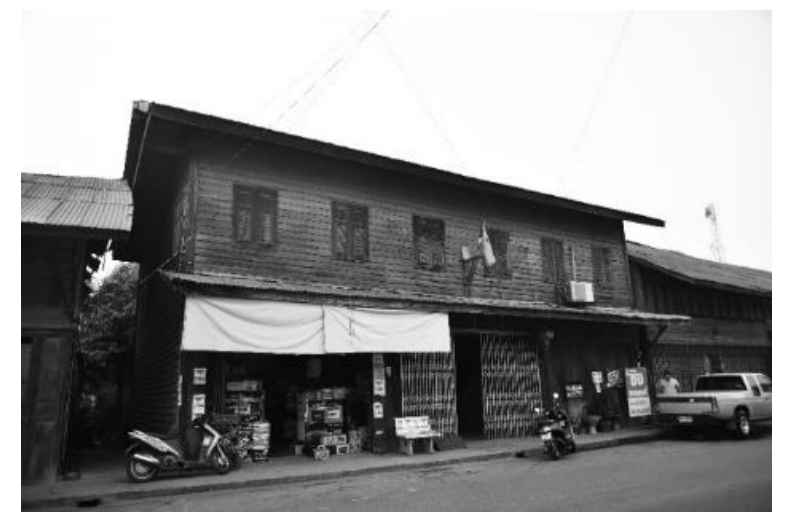

Figure 28 Khun prani building

\section{Three-story Hotel}

The Three storey hotel building was built because the popularity of worshiping Stone altar in Uttaradit Province and Phra Prang Old Town, Tha Chai. Therefore, people prefer to stay at Sawankhalok for one night, with accommodation fee ranging from 50 satang to 1 baht, according to the words from Thaworn holrangkul (Holrangkul, 2020). The hotel is divided into 2 floors with 9 rooms on the ground floor and 5 rooms on the upper floor, in total of 14 rooms. Currently, the hotel has close their business for over 20 years, while the current condition of the hotel are still in the good shape and still see the previous evident that represent the character of three storey hotel even some Hotel rooms inteior wood plank had been remove.

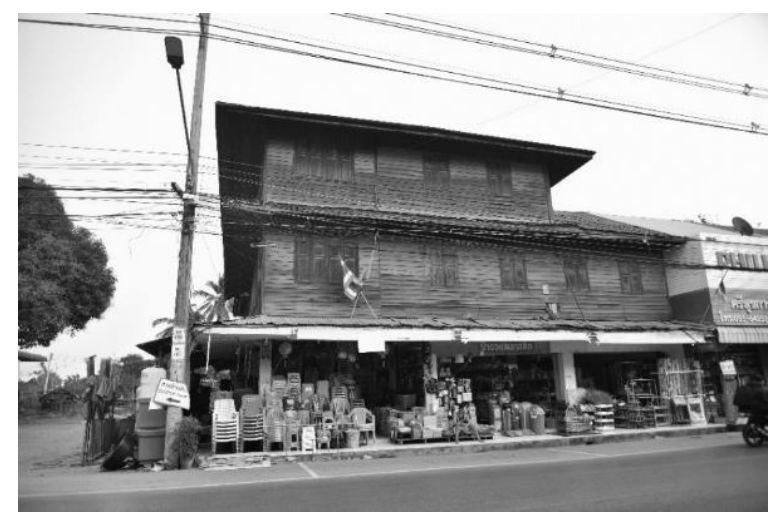

Figure 29 Three-story Hotel

\section{Rungkij building}

The Rungkit Building is a three-story wooden building with 4 row houses, built and originally owned by Chinese people and was sold to Khun Kasem and gave to his son, Mr. Sanguan Sukket. Then sold to Mr. Kasem Kengkarnka. Finally, the building was sold and handed over to Mr. Chaung Pattamayothin until present. The building are still runing the bussiness as a trading of construction equipment. (Pattamayothin, 2020) 


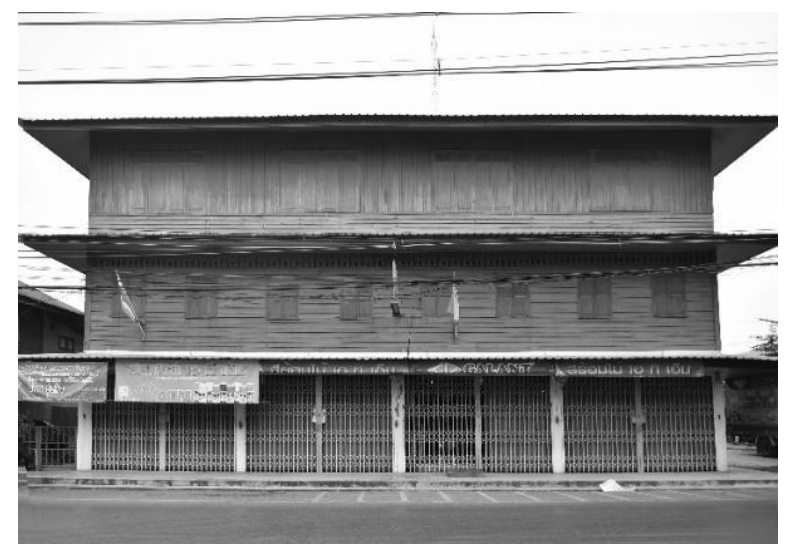

Figure 30 Rungkij building

\section{Nguan Yu Thai Rice miller}

The rice miller belongs to Khun Panya Piyachanya, 89 years old (Piyachanya, 2020). In the past, the rice miller uses stream power instead of Electricity to operate the machine. There were around 20 workers who are local people in Sawankhalok. The rice from this rice miller are exported around 70percent to Bangkok while 30percent remained in Sukhothai area. The building has a great value in term of architecture preservation because the building is in a good condition, and the structure of the building still in a good shape. Similarly, to the machine for rice miler which every equipment never been remove from the area. Moreover, the building represent the status of sawankhalok as one of the most important agriculture in the lower-northern part of Thailand and the culture of Sawankhalok people that related to agriculture.

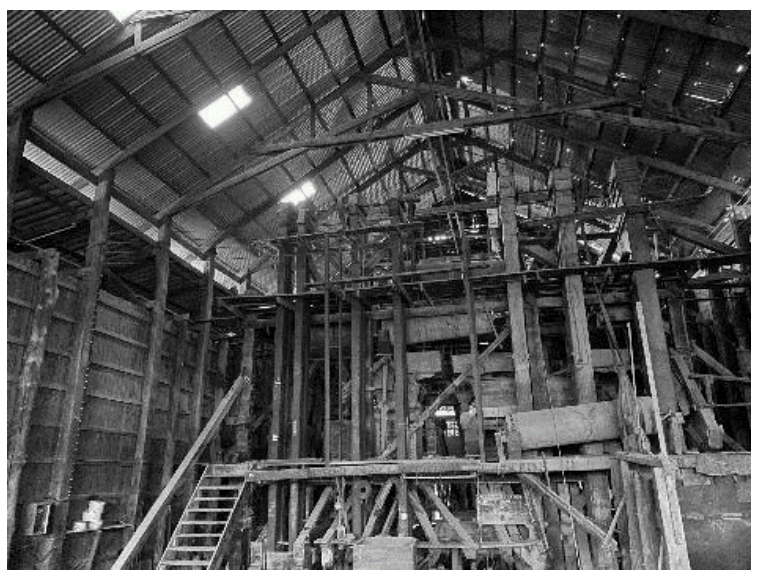

Figure 31 Nguan Yu Thai Rice miller

\section{Regeneration of Sawankhalok Community}

\section{Possibilities in the future: The Community based approach strategy}

After the survey and analysis of the Sawankhalok municipality. Local Community should be the foundation of every development in the district because local community could play an important role to promote and increase the tourism businesses in the area.

From the interview, it is obvious clear that the community and atmosphere of the place is one of the most attractive elements in the district. Moreover, the development to create sustainability output for the local people. The project should focus to create business and service that help local people and local business to help their self and allow them to support their community through this circular economy strategy that make the community get 
stronger and be able to rely on their self rather than support from the government or private sector to survive in the future. Moreover, if the local people and district are based their economic structure only on tourism business, this might create problem in the future because of tourism business may be unreliable and dependable on many external factors such as economy and political in the country.
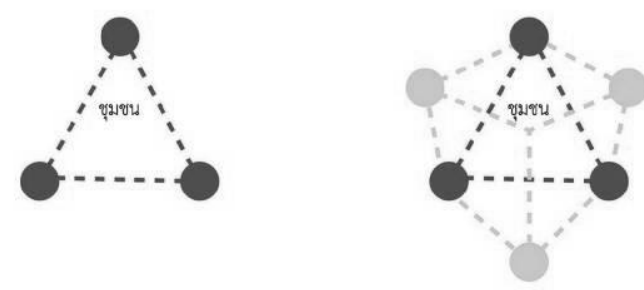

Figure 32 Community Based Approach Strategy Diagram

\section{Center of tourism destination in Sukhothai municipality}

Even though there are many attraction historical places that might attract people to travel around the place in Sawankhalok municipality, but some destination places has a great value in history but could not attract tourist to visit the place because of this, after evaluate and analysis through all the attraction places. As the result, there are several destination places which could give both value in history and travel to tourists. All the possible places are marked from the satellite map which is clear that the existing old district located in the middle of the all places, the research area has high potential to become the center of tourist destination in Sawankhalok municipality area.
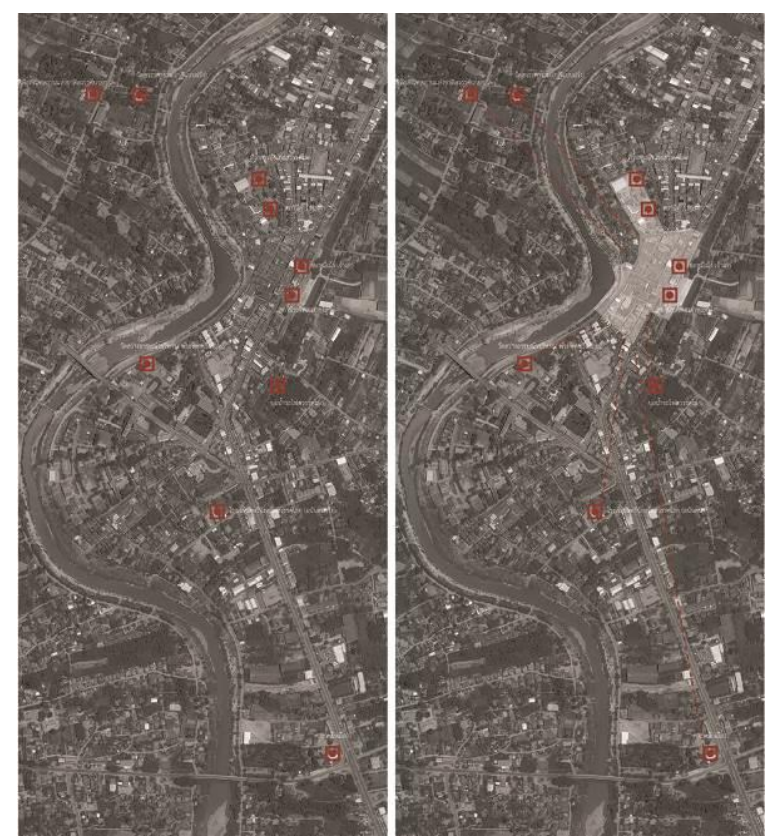

Figure 33 Center of Tourist Destination 


\section{Creating more attraction place in the old district area and provide diverse travel route for tourist people}

Currently, the city area of Sawankhalok are popular from the old train station and Graffiti arts along the old shop house in the district. This Attraction nodes could not create enough activities for tourism to stay at Sawankhalok area, while the local business are unable to receive income from tourism who have visit the area of the places because these two destination Street Art and the train station are not able to generate income for the community. Resulting in lack of income distribution to people and businesses in the area and surrounding. If the Sukhothai district could create and connect new destination places with the current attraction areas, it could help tourists to spend more time in the district and increasing income to the local people and expand the development to surrounding area.

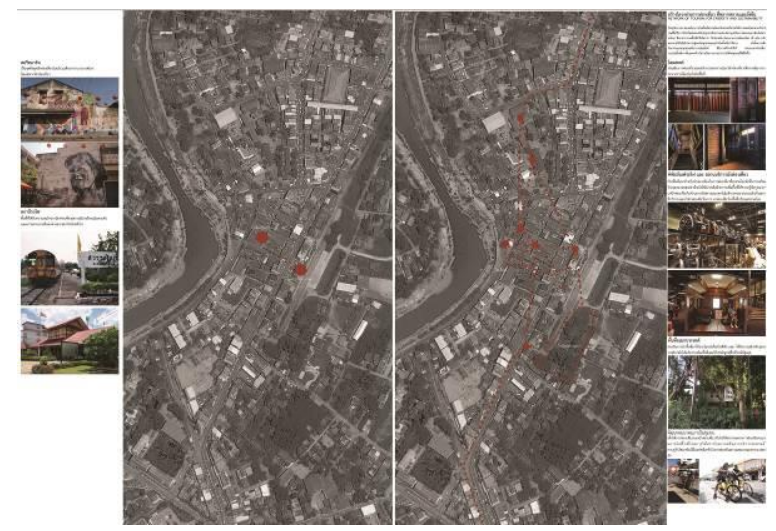

Figure 34 Creating Attraction places in Area

\section{Summarize Project for a new tourism route for Sawankhalok city.}

This tourism strategy started from brainstorming and participation between researcher and community, to create a most reasonable outcome that answer to every aspect and everyone in the community. Currently, tourists prefer to visit at the Sawnkhalok only the Street art and old community area which located opposite the train station, as the result, the tourism route in Sawankhalok is not enough and could not create income distribution to local people and surrounding.

After summarize every possibly solution for the community, The idea to promote a better tourism route for Sawankhalok could expand income to local businesses in the area and possibly generate a better economy to the city. A new tourism plan has studied through all the element which relate to the tourism, from existing places of museum, temple, restaurants, and accommodation.

Program has been developed by based on the existing attraction places and create connection with local businesses to provide income distribution to local people, moreover, establishing wood architecture in Sawankhalok could become a new destination for people to visit. Wood Architecture buildings in Sawankhalok has been added to the route to develop a new and diverse travel experience for people and provide the narrative to represent culture character of Sawankhalok for the visitors. 


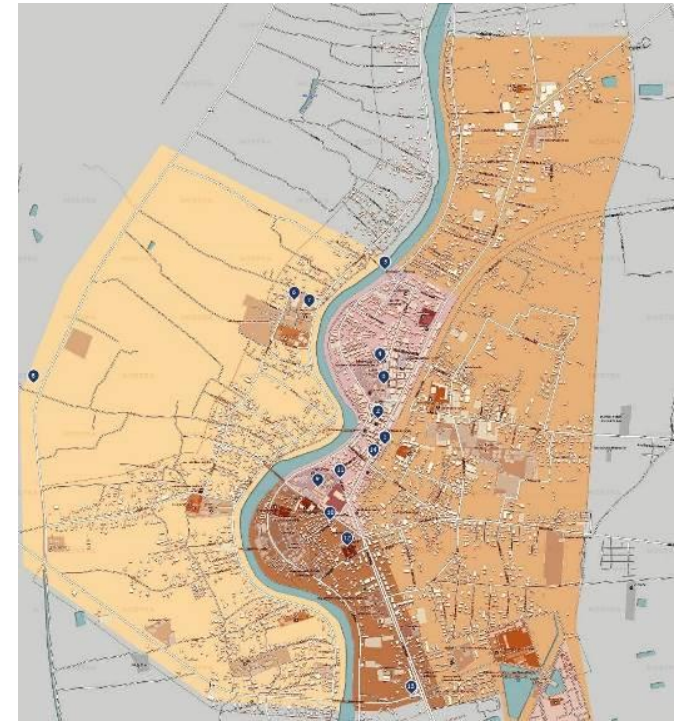

Figure 35 Attraction Places

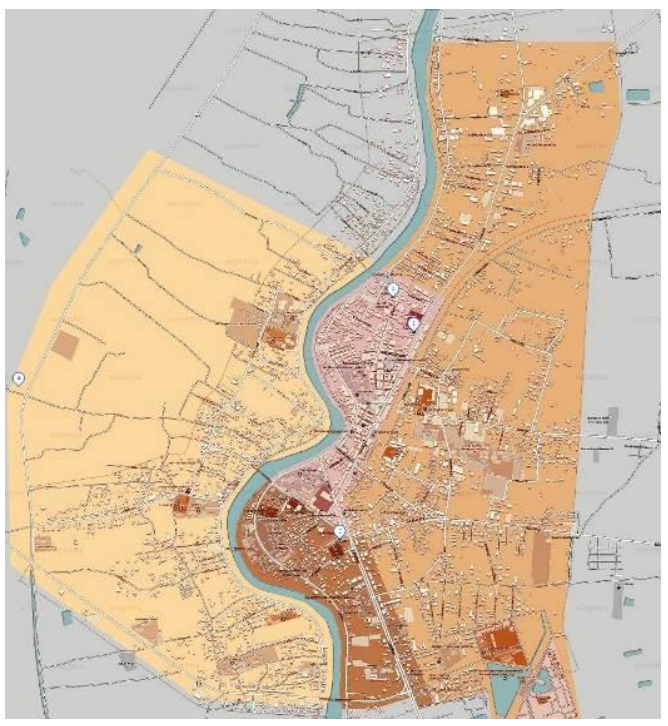

Figure 36 Accommodation Places 


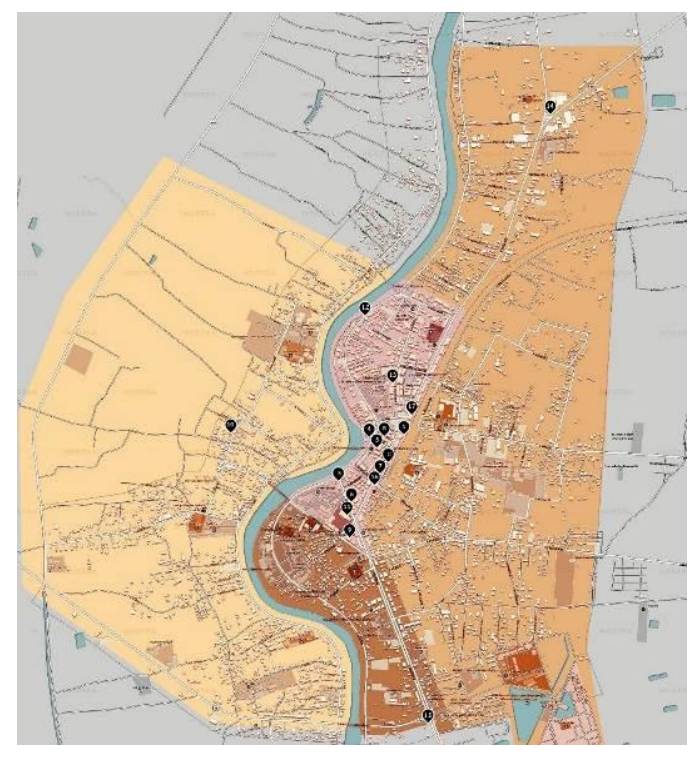

Figure 37 Restaurant Places

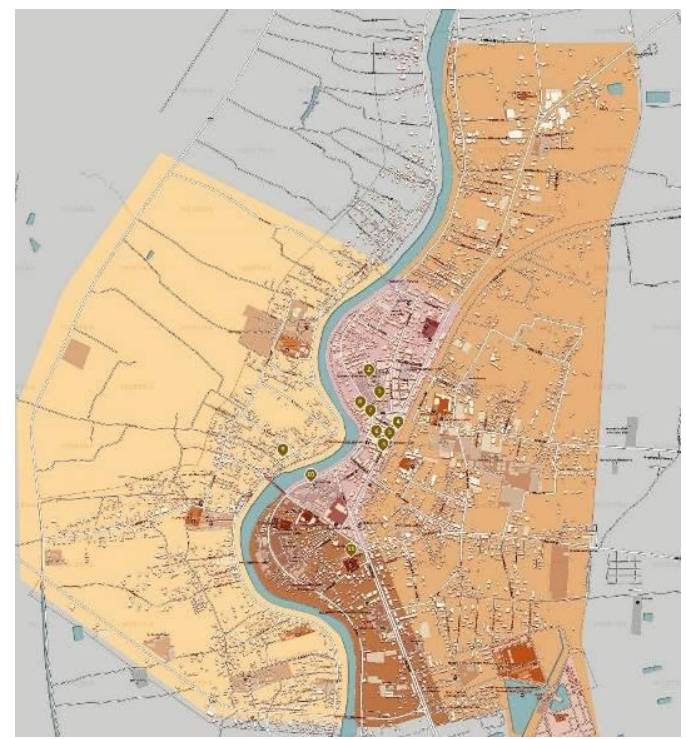

Figure 38 Wood Architecture Building

Finally, the plan is redesign for visitor to visit sawankhalok more than 1 day that allow visitors be able to involve with more activity and businesses in the area. While the transportation route are redesigned to relate with the interesting place in sawankhalok and provide the shortest route and convenient for the visitor to roam around the city. 


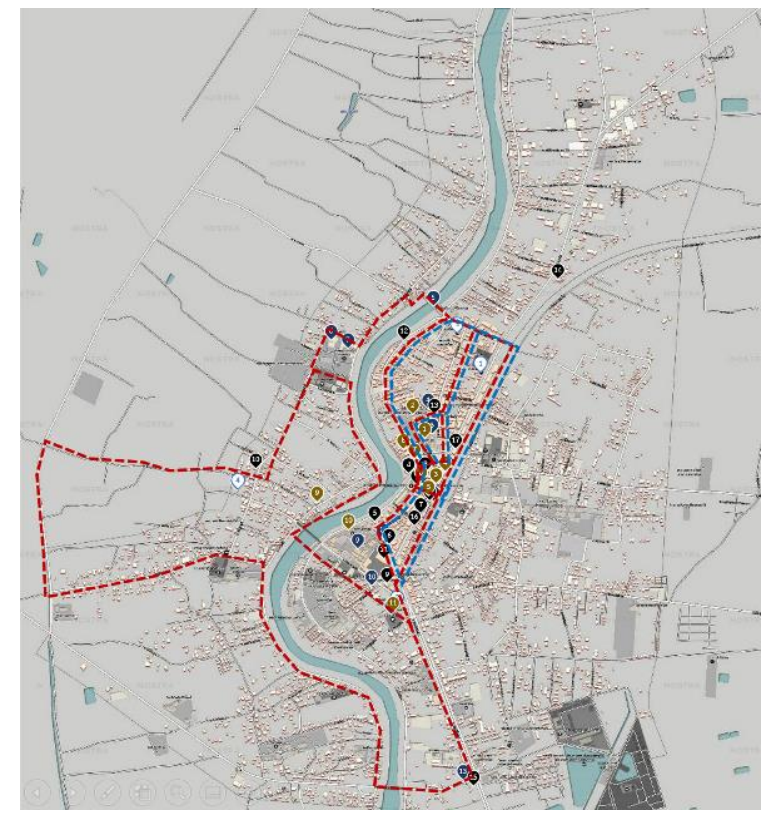

Figure 39 Final Route

\section{Multi discipline designed}

The project has concern about sustainable tourism which the community could be able to operate the tourist business by their self without any relate to outsider. The project has established the Gifted team which start from assign around 10-20 students who have a moderate English language skill and understand the interesting place in Sawankhalok. All of this student will be the guide tour that would provide help to visitor and tourist during their visit sawankhalok district.The Rebranding of Sign and logo for local community to increase the value of Sawankhalok culture and history that in the term of advertising.

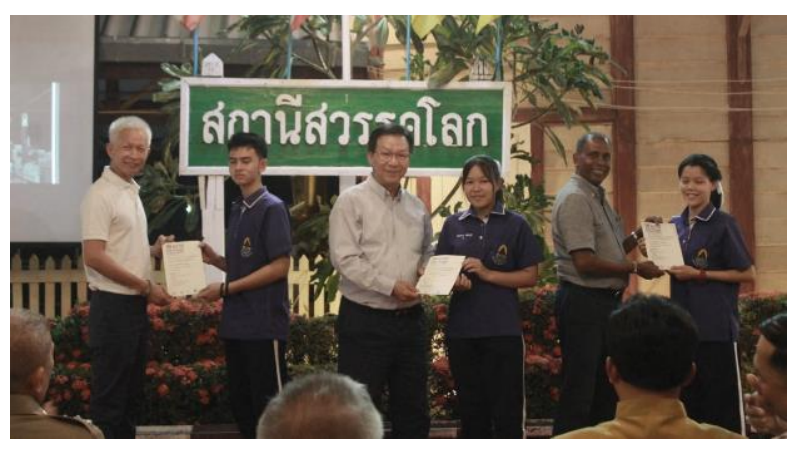

Figure 40 The Gifted team 


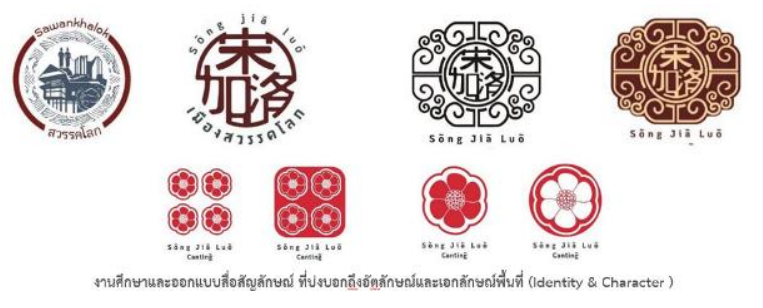

Figure 41 Logo Design

\section{Conclusion}

\section{Future of Sawankhalok Creative tourism}

In conclusion, it is undeniable that the current status of Sawankhalok is underestimated from the outsider. Even the city involved with a long history and unique culture, enhancing with a strong local community and many young generations that try to promote their home town to be a world tourism destination. After a field survey and research, it has shown that if the community applies Community based approach strategy to Sawankhalok, This will help to create a better tourism business for a better economy and a more sustainable community. While creating more attraction places inside the community generates more income and income distribution to all local businesses in the area, the project and idea are currently on the process of discussion to find a middle ground between different parties; researchers, government officers, and local people. The following method which already present from the above paragraph requires the amount of time to conduct a result but the outcome would create a long term benefit to all parties, and the possibility to study the impact of Community based approach strategy both in the short and long term in the future.

\section{References}

AntWorawit. (2016, July 23). PANTIP. Retrieved August 14, 2020, from สวรรคโลก อ๔ดด๐ [Freestyle Journey] (Sawankhalok 64110 freestyle Journey): https://pantip.com/topic/35411994 [Accessed 14 August 2020]

Ball State University, 2020. Study Abroad. [Online] Available at: https://www.bsu.edu/academics/collegesanddepartments/cap/current-students/study-abroad

Bunnag, T., 2005. การปกครองระบบเทศาภิบาลของประเทศสยาม พ.ศ. 2435-2458. 2nd ed. Bangkok: Thammasat University Press.

Cha-umpol, M., 2018. Muang Boran Journal. [Online] Available at: http://www.muangboranjournal.com/post/Sawankhalok-railway-station [Accessed 15 March 2020].

Chukaew, P. P., 2011. Railway Terminals: Architectural Heritage of Thailand, Bangkok: s.n.

Duenpen, S., 2019. Important Historical Area in Sawankhalok [Interview] (5 December 2019).

DASTA. (2019). หลงเสน่ห์ “สวรรคโลก” เมืองเก่าที่ถูกลืม (Sawankhalok enhancing city), DASTA (Designated Areas for Sustainable Tourism) [Online] Avaliablea at: https://tis.dasta.or.th/dastatravel/sawankhalok/ [Accessed 14 August 2020]

Fine Arts Department, n.d. Si Satchanalai Historical Park. [Online] Available at: http://virtualhistoricalpark.finearts.go.th/sisatchanalai/index.php/en/ [Accessed 31 March 2020].

Holrangkul, T., 2020. Three Storey Hotel in Sawankhalok [Interview] (20 February 2020).

Jindapracha, P., 2020. History of Khunprani Family [Interview] (3 March 2020).

Kaewsayar, P. \& Chamnongsri, N., 2012. Tourism Initiative: A New Way of Touring Thailand. Suranaree Journal of Social Science, Volume 6,1, p. 91-109. 
Kasornprom, W., 2017. [Online] Available at: https://www.matichon.co.th/columnists/news_547563

Konsilaat, 2019. ภาพเก่าสุโขทัยในอดีต ปี 2479- 2491 (Picture of Sukhothai in the past 1936-1948),oknation. [Online] Avaliable at: http://oknation.nationtv.tv/blog/wut2013/2019/09/09/entry-2[Accessed 14 August 2020]

Kraipakorn, D., n.d. King Prajadhipok's Institute. [Online] Available at: http://wiki.kpi.ac.th/index.php?title=\%E0\%B8\%A1\%E0\%B8\%93\%E0\%B8\%91\%E0\%B8\%A5\%E0\%B9\%80\% E0\%B8\%97\%E0\%B8\%A8\%E0\%B8\%B2\%E0\%B8\%A0\%Е0\%B8\%B4\%E0\%B8\%9A\%Е0\%B8\%B2\%E0\%B8 $\%$ A5[Accessed 15 March 2020].

Louhapensang, Chaturong; Kangkhao, Surasak. (2018). A study and Development of the Ceative Tourism Strategy Model for a World Heritage Site Area at the Historical Town of Si satchanalai: A Pathway for Connecting ASEAN Tourism Network Community. Tangible - Intangible Heritage - Design, Social and Cultural Critique on the past, present, and future, 119-129.

NIHAL, 2018. CapAsia. [Online] Available at: http://capasia.blogspot.com/Non-Formal education Sawankhalok district Sukhothai 2010. คู่มือแหล่งเรียนรู้เมืองสวรรคโลกขุดตามรอยมรดกท้องถิ่นจังหวัดสวรรคโลก [Learning guide for Sawankhalok district Sukhothai Province]. Sawankhalok: s.n.

Official Statistics Registration Systems, 1993. Population statistic by age of Sawankhalok district, Sukhothai province, Sawankhalok, Sukhothai: 2018.

Pattamayothin, A., 2020. Rungkij Building [Interview] (20 February 2020).

Piyachanya, P., 2020. Nguan Yu Thai Rice Miller [Interview] (3 March 2020).

Rajanubhab, D., 2002. เทศาภิบาล. 1st ed. Bangkok: Matichon.

Rockwood, H. S. I., 1995a. Cooperative and Collaborative Learning. The National Teaching and Learning Forum, Volume 4,6, pp. 8-9.

Rockwood, H. S. I., 1995b. Cooperative and Collaborative Learning. The National Teaching and Learning Forum, Volume 5,1, pp. 8-10.

Sawanvaranayok National Museum, 2020. Settlement history And ancient communities: Chaliang SiSatchanalai Chiangchuen Sawankhalok, Sawankhalok,Sukhothai: Sawanvaranayok National Museum.

Songsiri, W., 2016. Lek-Prapai Viriyahpant Foundation. [Online]

Available at: http://lek-prapai.org/home/view.php?id=827[Accessed 2 March 2020].

Sowittiyakul, K., 2020. History of Sermthai house [Interview] (3 March 2020).

Sukhothai Government, n.d. Sukhothai Information and Communication Information Group. [Online] Available at: http://www.sukhothai.go.th/history/hist_11.htm[Accessed 25 March 2020].

Thai Government Gazette, $1900 . \quad$ Ratchakitcha พระเจ้าน้องยาเธอกรมหลวงดำรงราชานุภาพสเด็จออกไปตรวจราชการมณฑลพิษณุโลก. [Online]

Av ailable at: http://www.ratchakitcha.soc.go.th/DATA/PDF/2443/021/259.PDF [Accessed 16 March 2020].

Thai Government Gazette, 1910. ratchakitcha การเปิดทางรถไฟอุตรดิษฐ์แลสวรรคโลก. [Online] Available at: http://www.ratchakitcha.soc.go.th/DATA/PDF/2452/D/2063.PDF [Accessed 15 March 2020].

The Association of Siamese Architects Under Royal Patronage, 2016. Asaconservationaward. [Online] Available at: https://asaconservationaward.com/index.php/2016-06-13-15-21-44/building-2559/415-sa-wankhalok-police [Accessed 5 March 2020].

United Nations Educational, Scientific, and Cultural Organization (UNESCO), n.d. Historic Town of Sukhothai and Associated Historic Towns. [Online] Available at: http://whc.unesco.org/en/list/574/[Accessed 6 November 2017].

Wattananikorn, P. K., 2018. British Teak Wallahs in Northern Thailand from 1876-1956. 1st ed. Bangkok: White Lotus Co.,Ltd.

Wikipedia, n.d. มณฑลเทศาภิบาล (province). [Online] Available at: https://th.wikipedia.org/wiki/\%E0\%B8\%A1\%E0\%B8\%93\%E0\%B8\%91\%E0\%B8\%A5\%E0\%B9\%80\%E0\%B8 
\%97\%E0\%B8\%A8\%E0\%B8\%B2\%E0\%B8\%A0\%E0\%B8\%B4\%E0\%B8\%9A\%E0\%B8\%B2\%E0\%B8\%A5

[Accessed 25 March 2020b].

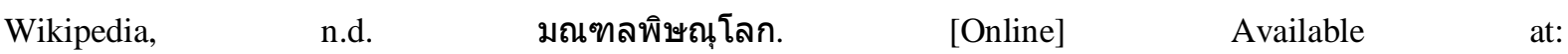
https://th.wikipedia.org/wiki/\%E0\%B8\%A1\%E0\%B8\%93\%E0\%B8\%91\%E0\%B8\%A5\%E0\%B8\%9E\%E0\%B8 $\% \mathrm{~B} 4 \% \mathrm{E} 0 \% \mathrm{~B} 8 \% \mathrm{~A} 9 \% \mathrm{E} 0 \% \mathrm{~B} 8 \% 93 \% \mathrm{E} 0 \% \mathrm{~B} 8 \% \mathrm{~B} 8 \% \mathrm{E} 0 \% \mathrm{~B} 9 \% 82 \% \mathrm{E} 0 \% \mathrm{~B} 8 \% \mathrm{~A} 5 \% \mathrm{E} 0 \% \mathrm{~B} 8 \% 81$ [Accessed 23 March 2020c].

Wikipedia, n.d. อำเภอสวรรคโลก [Sawankhalok District]. [Online] Available at: https://th.wikipedia.org/wiki/ [Accessed 10 March 2020a].

ราชการมณฑลพิษณุโลก. [Online] Available at:

http://www.ratchakitcha.soc.go.th/DATA/PDF/2443/021/259.PDF [Accessed 16 March 2020].

Thai Government Gazette, 1910. ratchakitcha การเปิดทางรถไฟอุตรดิษฐ์แลสวรรคโลก. [Online] Available at: http://www.ratchakitcha.soc.go.th/DATA/PDF/2452/D/2063.PDF [Accessed 15 March 2020].

The Association of Siamese Architects Under Royal Patronage, 2016. Asaconservationaward. [Online] Available at: https://asaconservationaward.com/index.php/2016-06-13-15-21-44/building-2559/415-sa-wankhalok-police [Accessed 5 March 2020].

United Nations Educational, Scientific, and Cultural Organization (UNESCO), n.d. Historic Town of Sukhothai and Associated Historic Towns. [Online] Available at: http://whc.unesco.org/en/list/574/ [Accessed 6 November 2017].

Wattananikorn, P. K., 2018. British Teak Wallahs in Northern Thailand from 1876-1956. 1st ed. Bangkok: White Lotus Co.,Ltd.

$\begin{array}{llll}\text { Wikipedia, } & \text { n.d. } \text { มณฑ Available }\end{array}$ at:https://th.wikipedia.org/wiki/\%E0\%B8\%A1\%E0\%B8\%93\%E0\%B8\%91\%E0\%B8\%A5\%E0\%B9\%80\%E0\% B8\%97\%Е0\%B8\%A8\%Е0\%B8\%B2\%Е0\%B8\%A0\%Е0\%В8\%B4\%Е0\%B8\%9A\%Е0\%B8\%B2\%Е0\%B8\%A5 [Accessed 25 March 2020b].

Wikipedia, n.d. มณฑลพัine] Available at: https://th.wikipedia.org/wiki/\%E0\%B8\%A1\%E0\%B8\%93\%E0\%B8\%91\%E0\%B8\%A5\%E0\%B8\%9E\%E0\%B8 \%B4\%E0\%B8\%A9\%Е0\%B8\%93\%Е0\%B8\%B8\%E0\%B9\%82\%E0\%B8\%A5\%Е0\%B8\%81 [Accessed 23 March 2020c].

Wikipedia, n.d. อำเภอสวรรคโลก ]Sawankhalok District]. [Online] Available at: https://h.wikipedia.org/wiki/ [Accessed 10 March 2020a]. 